\author{
Anna Emmanuela Klich OSU ${ }^{1}$ \\ Uniwersytet Papieski Jana Pawła II w Krakowie
}

\title{
Modlitwa o dar rozeznawania woli Boga (Flp 1, 9-11)
}

\section{Streszczenie}

Celem tego artykułu było zbadanie, jak św. Paweł rozumie rozeznawanie woli Boga w życiu wierzących. Egzegeza modlitwy wstawienniczej apostoła zanoszonej do Boga za Filipian (1, 9-11) wskazuje na to, że rozeznawanie jest przede wszystkim darem, łaską Boga, o którą warto prosić dla siebie i dla innych, dla Kościoła.

Apostoł Narodów podkreśla, że rozeznawanie łączy się ściśle ze wzrostem w miłości, ale też z otwieraniem się na poznanie objawiającego się Boga. Kluczową kwestią w rozeznawaniu - dla Pawła - jest odnajdywanie tego, co jest faktycznie wartościowe. Odczytując tę zasadę poprzez Rz 12, 2 można przyjąć, że chodzi o to, co dobre - w znaczeniu - pomocne do zbawienia, o to w czym Bóg ma upodobanie, czyli o czystość serca i całkowite ofiarowanie się Jemu oraz o to, co doskonałe, dojrzałe.

Treść tej modlitwy wstawienniczej zdaje się uwrażliwiać wierzących na działającego Boga, od którego pochodzi dar miłości, rozpoznawania i wybierania tego, co sprawia, że podobieństwo wierzących do Chrystusa coraz wyraźniej się uwidacznia.

Słowa kluczowe: rozeznawanie, wola Boga, modlitwa, zbawienie, czystość serca, dojrzałość

\section{Summary}

Prayer for the Gift of Discernment of the Will of God (Phil 1:9-11)

The purpose of this article is to investigate how Saint Paul understands the discernment of God's will in the life of believers. The exegesis of the intercessory prayer of the Apostle addressed to God for the Philippians (1:9-11) indicates that

1 Anna Emmanuela Klich OSU (ORCID: 0000-0001-8481-0745) - dr hab., adiunkt z habilitacją w Katedrze Teologii i Informatyki Biblijnej WT UPJPII w Krakowie, ekspert na Synodzie Biskupów o nowej ewangelizacji w Kościele, członek Międzynarodowej Komisji Katechetycznej (CoInCat) przy Papieskiej Radzie ds. Krzewienia Nowej Ewangelizacji. E-mail: anna. klich@upjp2.edu.pl. 
discernment is above all a gift, a grace of God, worth asking for, for oneself and for others, and for the Church.

The Apostle of Nations emphasizes that discernment is closely connected with growth in love, but also with opening to the knowledge of the God who makes himself known.

The key issue in discernment, for Paul, is to discover what is actually of true value.

Reading this principle in the light of Rom 12:2 one can assume that it is about what is good, in the sense of helpful to salvation, about what pleases God, that is, purity of heart and total sacrifice to Him, and about what is perfect, mature.

The content of this intercessory prayer seems to sensitize believers to the God at work within them, the God from whom comes the gift of love, and the gift recognizing and choosing what makes the likeness of believers to Christ more clearly manifest.

Keywords: discernment, God's will, prayer, salvation, purity of heart, maturity

Troska o wypełnienie woli Boga w życiu codziennym jest przejawem ważnego etapu na drodze ku dojrzałości chrześcijańskiej. Wierzący zjednoczony z Chrystusem przez chrzest stara się żyć w miłości i prawdzie oraz naśladować Go w posłuszeństwie Ojcu. Warto jednak zapytać, jak rozpoznać wolę Boga? Jak nią żyć w codzienności?

W pierwotnym Kościele przyznawano rozeznawaniu ważną rolę i posiadało wymiar osobisty oraz wspólnotowy. Święty Paweł w swoich listach zachęca wierzących do badania samych siebie (por. 2 Kor 13, 5). Zauważa, że Bóg bada chrześcijan (por. 1 Tes 2, 4). Wskazuje na potrzebę sprawdzenia osób przed powierzeniem im posługi we wspólnocie (por 1 Tm 3, 10). W Liście do Rzymian, na początku części parakletycznej $(12,2)$ apostoł wskazuje na zależność zachodzącą między przemianą życia a umiejętnością rozeznawania.

Początek Listu do Filipian, zawierający jego modlitwę wstawienniczą, wnosi do tematu rozeznania akcent szczególny. Paweł modli się o ten dar dla ochrzczonych (Flp 1, 9-11). Analiza perykopy pozwala wyróżnić następujące zagadnienia dotyczące daru rozeznawania woli Bożej: 1) Prośba o wzrost miłości; 2) Wybór tego, co wartościowsze; 3) Perspektywa wieczności. 


\section{Prośba o wzrost miłości}

Święty Paweł rozpoczyna List do Filipian prologiem (1, 3-11), który składa się z pozdrowień (w. 1-2) oraz z modlitwy dziękczynnej i wstawienniczej za wspólnotę (w. 3-11). Wydaje się, że stanowi ona echo modlitwy żydowskiej (por. 2 Mch 1, 3-5) i posiada też własne akcenty. Rozwi-

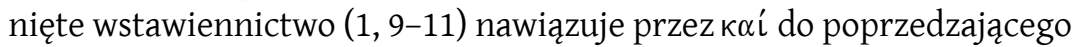
go dziękczynienia i odbywa się w trzech krokach. Dwukrotnie występuje spójnik: " $\nu \alpha$ „aby”, „żeby” - rozpoczynający zdanie celowe (w. 9.10) oraz zdanie imiesłowowe - temu odpowiada trzykrotne użycie przyimka $\epsilon i \varsigma$ „do”, „ku”). Staranna budowa nadaje modlitwie pewną wyjątkowość Apostoł odsłania przed adresatami istotę błagalnego wstawiennictwa, kierowanego do Boga za wspólnotę (Flp 9-11) ${ }^{3}$. Najpierw Apostoł Narodów „modli się” o to, by miłość Filipian „ciągle wzrastała”. Następnie prosi Boga, by towarzyszyło jej głębsze poznanie i wszelkie wyczucie, a także by umieli ocenić, co jest lepsze, aby byli czyści i bez zarzutu na dzień Chrystusa oraz żeby byli napełnieni plonem sprawiedliwości nabytym przez Jezusa Chrystusa ku chwale i czci Boga.

Pierwszą prośbą w modlitwie wstawienniczej Pawła za Filipian jest: „aby [wasza] miłość wasza wzrastała coraz bardziej i bardziej” (w. 9 b). Chodzi o ciągły rozwój miłości, podczas którego poszerza się jej zakres.

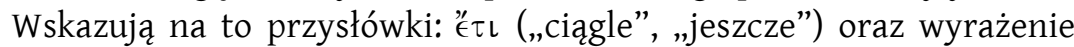

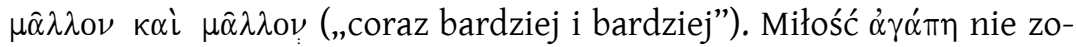
stała tu w żaden sposób opisana. Można więc przyjąć, że jest to „miłość Boża rozlana w sercach naszych przez Ducha Świętego, który został nam dany" (Rz 5, 5). Jej cechy wysławia Paweł w hymnie o miłości (1 Kor 13)4. Apostoł Narodów podkreśla, że miłość, jaką wierzący zostali obdarowani

2 Por. J. Gnilka, Der Philipperbrief, Freiburg-Basel-Wien 1968, s. 51 (Herders Theologischer Kommentar zum Neuen Testament, 10).

3 Por. M.S. Wróbel, Dziękuję Bogu mojemu, z powodu każdego waszego wspomnienia-zawsze w każdej mojej modlitwie... (Flp 1, 3n), w: Modlitwa dziękczynienia. Homo Orans, red. J. Misiurek, J.M. Popławski, K. Burski, Lublin 2005, s. 19-29 (Homo Orans, 6).

4 Por. T. M. Dąbek, Hymn o miłości (1 Kor 12, 31-13, 13), w: Aby rozważać Pismo Święte, Kraków 2011, s. 187-199. Ciekawy komentarz cech miłości daje papież Franciszek w Posynodalnej adhortacji apostolskiej Amoris laetitia (19 marca 2016), Kraków 2016, 90-119. 
przez Boga jest darem dynamicznym, wymagającym pomnażania i dzielenia się nim. Paweł, widząc związek pomiędzy miłością a rozeznawaniem, modli się, by miłość Filipian stawała się coraz bardziej doskonalsza, aby doskonaliła się w nich umiejętność skutecznego rozeznawania dla wyczucia i „oceny tego, co lepsze”, tego, co należy czynićs . O tej samej prawdzie daje również świadectwo św. Faustyna, które pisze:

gdy dusza moja zanurzona jest w miłości, to najwięcej zawiłe kwestie jasno i prędko rozstrzygam - ona jest zdolna przejść nad przepaściami i przez wierzchołki gór. Miłość, jeszcze raz miłość.

Kluczowy dla pierwszej prośby Pawła, która dotyczy „miłości” jest czasownik $\pi \epsilon \rho \iota \sigma \sigma \epsilon u ́ \omega$ oznaczający „przekraczać ustaloną miarę”, „pozostawać ponad miarę, która została określona”; „istnieć, bądź być dostępnym w obfitości”; „być wielkim”; „być obficie zaopatrzonym w coś”, „mieć w obfitości”, „obfitować w coś”, „mieć dostatek”; „przodować”, „wybijać się”; „wyróżniać się”, „przewyższać”. Czasownik ten występuje dosyć często w Corpus Paulinum ${ }^{8}$. Paweł używał go wielokrotnie na wyrażenie obfitości udzielanych przez Boga łask (Rz 15, 13; 2 Kor 4, 15; 8, 7; 9, 8). W Liście do Filipian $(1,26)$ Apostoł stosuje go w odniesieniu do adresatów, którzy mogą się cieszyć z tego i za to Bogu dziękować, co on, w Chrystusie, dla nich uczyni, kiedy znowu do nich przybędzie'. Paweł stwierdza, że w sytuacji skrajnych warunków życia - głodu czy obfitości - czerpana z wiary moc Chrystusa uczyła go koniecznego dystansu przy wypełnianiu zleconej misji (por. Flp 4, 12). W szerszym kontekście według Corpus Paulinum Apostoł Narodów wskazuje na Boga, który ubogaca nadzieją (por. Rz 15, 13), łaską (por. 2 Kor 9, 8). Ponadto wzrasta chwała Boża (por. 2 Kor 9, 8), doskonałość (por. 1 Tes 4, 1) i mądrość

5 Por. A. Ruszała, W dobrych zawodach. Rozeznanie i walka duchowa w życiu chrześcijańskim, Kraków 1999, s. 33.

6 F. Kowalska, Dzienniczek. Miłosierdzie Boże w duszy mojej, Warszawa 1993, nr 1132.

7 J. Strong, LL.D., S.T.D, Grecko-polski słownik Stronga z lokalizacją słów greckich i kodami Popowskiego, Warszawa 2015, G4052.

8 Czasownik $\pi € \rho \iota \sigma \sigma \epsilon u ́ \omega$ występuje w NT 39 razy, z czego w Corpus Paulinum aż 26 razy.

9 Por. J. Flis, List do Filipian, Częstochowa 2011, s. 446 (Nowy Komentarz Biblijny. Nowy Testament [dalej: NKB NT], 11). 
(por. Ef 1, 8). Z perspektywy Pawła, dzięki dziełu zbawienia, ludzie „obfitują we wszystko, w wiarę, w mowę, w wiedzę, we wszelką gorliwość,

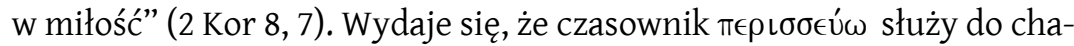
rakteryzowania nowych czasów zainaugurowanych przez Chrystusa. W badanym miejscu św. Paweł zaświadcza, iż miłość Boża dana chrześcijanom jako dar Ducha Świętego ma nieustannie wzrastać i w każdych okolicznościach obejmować swym zasięgiem więcej osób.

Wzrost miłości łączy Paweł najpierw z émí $\gamma \nu \omega \sigma \iota \varsigma$, to znaczy z „poznaniem”, ze „szczególną wiedzą” odnoszącą się do spraw Bożych. Poza badanym miejscem rzeczownik €̇í $\gamma \nu \omega \sigma \iota \varsigma$ w Corpus Paulinum stosowany jest wielokrotnie ${ }^{10}$. Przykładowo w Liście do Rzymian $(1,28)$ Apostoł Narodów zauważa, że prawdziwe poznanie Boga trzeba wiernie zachować, gdyż jest ono darem i łaską. Jeśli tego zabraknie, ludzie zawierzają własnemu rozumowi i wchodzą na drogę grzechu, niegodną chrześcijan, lub szukają własnych dróg usprawiedliwienia, a „nie poddają się uspra-

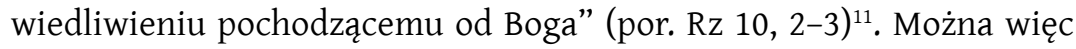
przyjąć, że nie chodzi tu o poznanie zmysłowe czy intelektualne, ale pochodzące od objawiającego się Boga, które konieczne jest do przyjęcia daru zbawienia.

Drugim warunkiem wzrostu miłości jest $\alpha$ Ł̋ $\sigma \eta \emptyset \sigma \varsigma$, czyli „postrzeganie, nie tylko zmysłami, ale i intelektem”; „poznanie”, „rozeznanie”12.

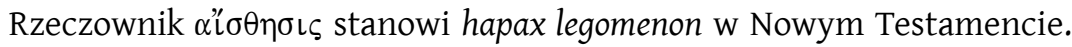
W LXX występuje czasownik z nim związany, który może oznaczać spostrzeganie zmysłowe $(B a 6,19)$ oraz osąd moralny (Prz 17, 10), jak i religijny (Iz 49, 26). Można więc przyjąć, że w badanym miejscu chodzi o moralną, etyczną zdolność osądu ${ }^{13}$. Poznanie spraw Bożych wspomaga świadomość moralną i duchową.

10 Por. 1) O poznaniu Boga Ojca: Rz 1, 28; 10,2; Ef 1, 17; Kol 1, 10; 3, 10; 2) O poznaniu Syna Bożego: Ef 4, 13; Flp 1, 9; 3) O poznaniu woli Boga, objawionej prawdy: Kol 1, 9; $1 \mathrm{Tm}$ 2, 4; 2 Tm 2, 25; 3, 7; Tt 1, 1; Flm 6; Hbr 10, 26; 4) O poznaniu grzechu: Rz 3, 20.

11 Por. Ef 1, 17; 4, 13; Kol 1, 9.10; 2, 2; 3, 10; 1 Tm 2, 4; 2 Tm 2, 25; 3, 7; Tt 1, 1; Flm 1, 6. Ponadto występuje on Liście do Hebrajczyków $(10,26)$ oraz w Drugim Liście św. Piotra $(1,2.3 .8$; $2,20)$.

12 Por. J. Strong, LL.D., S.T.D, Grecko-polski słownik Stronga z lokalizacją słów greckich $i$ kodami Popowskiego, dz. cyt., G144.

${ }_{13}$ Por. J. Flis, List do Filipian, dz. cyt., s. 114. 
Modlitwa św. Pawła wskazuje na to, że trwanie wierzących w miłości Boga jest darem, który wymaga dynamicznego wzrostu. Wzrost ten związany jest z łaską stałego otwierania się na poznanie objawiającego się Boga oraz prowadzi chrześcijanin do dojrzałości widzenia i oceny rzeczywistości. Jednocześnie Paweł podkreśla, że fundamentem rozeznawania w wierze jest miłość Boga i przejawia się w miłości bliźniego.

\section{Wybór tego, co wartościowsze}

Wzrost miłości Paweł ściśle łączy z darem rozeznawania. Winna ona obfitować dzięki wartościowym wyborom w codzienności wierzących (w. 10b). Pomocną w rozumieniu tej frazy może okazać się analiza zna-

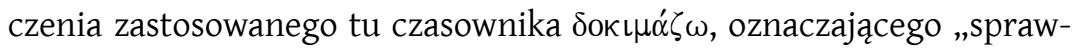
dzać”, „próbować”, „analizować, czy coś jest prawdziwe, czy nie”, „uznać za prawdziwe po badaniu”, „aprobować”, „uznać za godne”14.

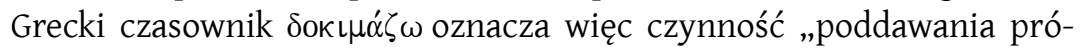
bie”, „badania kogoś lub czegoś” oraz „osiąganie celu próby, jakim jest rozpoznanie czegoś jako dobre, wartościowe, wypróbowane lub kogoś jako dobrego i wypróbowanego" ${ }^{15}$. Przykładowo w Drugim Liście do Koryntian Paweł zachęca wierzących do sprawdzania i analizowania, reflektowania nad swoją wiernością Chrystusowi: „siebie samych badajcie, czy trwacie w wierze, siebie samych doświadczajcie!" $(13,5)^{16}$. Zawarte tu napomnienie jest zachętą dla chrześcijan, by byli krytyczni wobec samych siebie i stawiali sobie pytanie, czy ich postępowanie odpowiada

14 Por. J. Strong, LL.D., S.T.D, Grecko-polski słownik Stronga z lokalizacją słów greckich $i$ kodami Popowskiego, dz. cyt., G1381.

15 Por. R. Popowski, Wielki słownik grecko-polski Nowego Testamentu, Warszawa 2006, 1378. Występuje w odniesieniu do Boga badającego serce człowieka. W Pierwszym Liście do Tesaloniczan św. Paweł ukazuje wierzącym Boga badającego ludzkie serca i wskazuje, że motywem głoszenia Ewangelii jest pragnienie tego, by Bogu się podobać. Pisze: ,jak przez Boga zostaliśmy uznani za godnych powierzenia nam Ewangelii, tak głosimy ją, aby się podobać nie ludziom, ale Bogu, który bada nasze serca" $(2,4 b)$.

16 Por. H. Langkammer, Pismo Święte Starego i Nowego Testamentu. Pierwszy i Drugi List do Koryntian. Tłumaczenie. Wstęp i Komentarz, Lublin 1998, s. 190. W Pierwszym Liście do Ty-

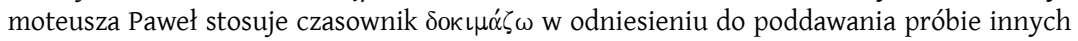
ludzi - diakonów: „Oni niech będą najpierw poddawani próbie, i dopiero wtedy niech spełniają posługę, jeśli są bez zarzutu $(3,10)$. 
darowi wiary oraz obecności Chrystusa w sercach każdego z nich oraz całych wspólnot ${ }^{17}$. Święty Teodoret z Cyru proponuje, by kryterium badania tego, czy chrześcijanie są utwierdzeni w wierze jest żywa obecność Chrystusa w nich. W Komentarzu do Drugiego Listu do Koryntian stwierdza:

Nie zastanawiajcie się nad naszymi sprawami, ale popatrzcie na samych siebie i rozważcie, czy naprawdę jesteście utwierdzeni w wierze. Czy nie wiecie o samych sobie, że Jezus Chrystus jest w was, chyba że niezdatni jesteście? Trzeba bowiem byście wiedzieli, że gościcie samego Chrystusa Pana, który w was jest. Kto tego nie wie, ten nie ma wiary ${ }^{18}$.

W innym miejscu Apostoł zaświadcza też o wypróbowaniu osób, co do których wielokrotnie doświadczył, że są gorliwi (por. 2 Kor 8, 22).

W badanej perykopie Apostoł Narodów wskazuje na potrzebę poddania próbie rzeczy, czy są dobre i wartościowe, a następnie aprobowania i wybierania tego, co jest bardziej wartościowe (por. Flp 1, 10). Z czasow-

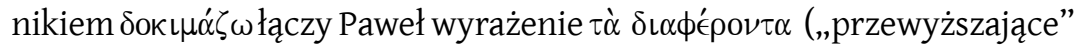
[dobra, wartości]), które wskazuje na to, co jest lepsze, więcej warte, „na rzeczy mające prawdziwe znaczenie"19. Można tu widzieć dalsze przygotowanie do późniejszej zachęty Pawła, skierowanej do Filipian, w której domaga się, by chrześcijanie dokonywali właściwego wyboru. Jest nim droga Jezusa, który wybrał najlepiej, droga uniżenia i posłuszeństwa Ojcu aż do śmierci $(2,6-8)^{20}$. Także Paweł potrafił właściwie wybrać tzn. „najwyższą wartość - poznanie Chrystusa Jezusa (...) dla którego odrzucił (wszystkie dotychczasowe osiągnięcia) i uznał je za łajna, byleby pozyskać Chrystusa" (por. 3, 8). Wierzący również są zaproszeni, by wybrać i trzymać się mocno Słowa Życia $(2,16)$, nie iść za wrogami Krzyża, którzy źle wybrali. W tym rozstrzygającym wyborze warto naśladować Apostoła

17 Por. A. Paciorek, Drugi List do Koryntian, Częstochowa 2017, s. 557n (NKB NT 8).

18 Por. Teodoret z Cyru, Komentarz do 1 i 2 Listu do Koryntian, Kraków 1998, s. 161 (Źródła Myśli Teologicznej, 8).

19 Por. R. Popowski, Wielki słownik grecko-polski Nowego Testamentu, dz. cyt., 1301.

20 Por. S. Witkowski, Upokorzony i uwielbiony Chrystus (Flp 2, 6-11), „Ruch Biblijny i Liturgiczny" 61 (2008) 1, s. 29-38; por. także: A. Kasprzyk, Znaczenie kenozy Chrystusa dla jedności wspólnoty, w: Powołani do komunii z Bogiem i człowiekiem, red. A. E. Klich, Kraków 2011, s. 51-76 (Duc in Altum, 12). 
Narodów $(3,17)^{21}$. Wydaje się, że Paweł usiłuje umotywować adresatów listu do świadomego życia i refleksyjności w decyzjach.

Podobną myśl dotyczącą rozeznawania tego, co bardziej wartościowe w życiu chrześcijańskim św. Paweł wprowadza w Liście do Rzymian $(12,1-2)$. W perykopie dotyczącej całkowitego oddania się Bogu w ofierze autor stosuje najpierw dwa imperatywy. Pierwszy z nich ma formę nega-

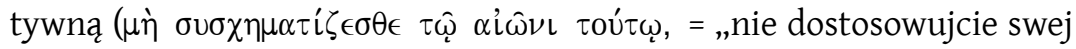
postaci do wieku tego"), a drugi pozytywną ( $\mu \epsilon \tau \alpha \mu \rho \phi o v ̂ \sigma \theta \epsilon=$,dajcie

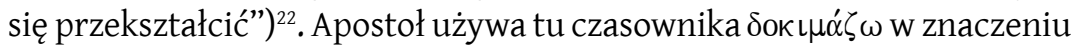
„próbować”, „rozeznawać” wolę Boga. To zestawienie zdaje się wskazywać na zależność zachodzącą między poznaniem woli Bożej a duchową metamorfozą, która ma dotyczyć „odnowienia myśli”. Przez zastosowany rzeczownik đ่ $\nu \alpha \kappa \alpha i ́ \nu \omega \sigma \iota \varsigma$ oznaczający „odnowienie”, „odświeżenie”, „całkowitą zmianę na lepsze” 23 Paweł sugeruje, że chodzi o odnowę dotyczącą istoty osoby. Rzeczownik ten obecny jest jeszcze w Liście do Tytusa $(3,5)$, gdzie autor listu odnosi go do chrztu jako dzieła Ducha Świętego odnawiającego chrześcijanina ${ }^{24}$. Skutkiem tego odnowienia jest „nowe

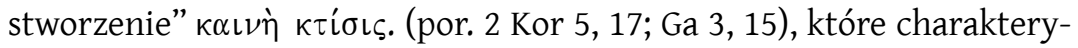
zuje pojednanie z Bogiem i odrzucenie norm świata ${ }^{25}$. Paweł wskazuje tu na taką istotową przemianę, której skutkiem jest życie w Chrystusie. Jest to owoc dzieła zbawczego Boga udzielonego wierzącemu w chrzcie.

Powracając do kontekstu Listu do Rzymian warto podkreślić, że chrześcijanin na mocy Bożego daru przemiany jest uzdolniony do tego, by rozeznawać ,jaka jest wola Boża: co jest dobre, podobające się Bogu i dojrzałe”

${ }^{21}$ Por. J. Flis, List do Filipian, dz. cyt., s. 114.

22 Por. H. Langkammer, Pismo Święte Starego i Nowego Testamentu w przekładzie z języków oryginalnych. List do Rzymian. Tłumaczenie. Wstęp. Komentarz, Lublin 1999, s. 155; por. także: D. Kramarz, Analiza struktury literackij Rz 12, 1-21, w: Hermeneutyka Pisma Świętego w Kościele. Wokół adhortacji „Verbum Domini” Benedykta XVI o słowie Bożym w życiu i misji Kościoła,, red. R. Pindel, S. Jędrzejewski, seria: Hermeneutica et Judaica, t. VI, Kraków 2012, s. 123-152.

${ }_{23}$ Por. J. Strong, LL.D., S.T.D, Grecko-polski słownik Stronga z lokalizacją słów greckich $i$ kodami Popowskiego, dz. cyt., G342.

${ }_{24}$ A. Gieniusz, Boże miłosierdzie jako źródło chrześcijańskiego nonkonformizmu $\mathrm{Rz} 12,1-2$, „Verbum Vitae” 2 (2003) 3, s. 152.

25 Por. J. R. Levison, Stworzenie i nowe stworzenie; w: Słownik teologii św. Pawła, red. G. F. Hawthorne, R. P. Martin, D. G. Reid, Warszawa 2000, s. 792-793. 
$(\mathrm{Rz} 12,2)^{26}$. Autor listu wskazuje na cztery kryteria rozeznawania wierzą-

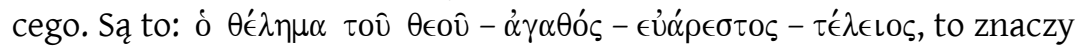
„wola Boga” - „dobre” - „podobające się Bogu” - „dojrzałe”.

Pierwszym kryterium rozeznawania jest wola Boga (por. Rz 12, 2). Najpierw warto postawić pytanie o to, co Paweł rozumie pod wyrażeniem:

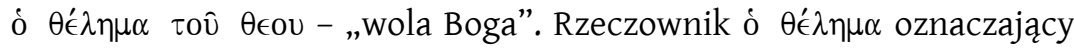
„to, co ktoś pragnie bądź postanowił robić”, odnoszony jest do „zamiaru Boga, aby pobłogosławić ludzi w Chrystusie”, do „tego, co Bóg pragnie byśmy czynili (przykazania)”. Ponadto oznacza „,wolę”, ,wybór”, ,,kkłonność”, „pragnienie”, „upodobanie”27. W Nowym Testamencie występuje wiele razy ${ }^{28}$. Pierwszy, podstawowy aspekt woli Boga, jaki Paweł podkreśla, to ten, iż zgodnie z wolą Boga Chrystus „wydał samego siebie za nasze grzechy, aby wyrwać nas z obecnego złego świata" (Ga 1,3-4). Przez swoją mękę, śmierć i zmartwychwstanie Chrystusa wyzwolił ochrzczonych z niewoli zła, grzechu i śmierci. Wola Boga ma przede wszystkim charakter zbawczy i dlatego, odniesiona do człowieka, dotyczy jego udziału w owocach dzieła odkupienia dokonanego przez Chrystusa. Następnie, Paweł zauważa, że z woli Boga stał się on apostołem Chrystusa (1 Kor 1, 1; 2 Kor 1, 1; 2 Tm 1, 1) i misję swą wypełnia zgodnie z wolą Boga (Rz 1, 10; Rz 15, 32). Oznacza to, że Bóg wybiera i posyła ludzi do głoszenia zbawienia w Jezusie Chrystusie. Wynikający z tego klucz do rozeznawania wskazuje na potrzebę wybierania tego, co jest związane ze zbawieniem, tego, co prowadzi do zbawienia. Ponadto chodzi o zaangażowanie w życiową misję oraz świadectwo i wybór tego, co innym może pomóc otworzyć się na dar zbawienia.

26 P. Gryziec, Rozpoznać wolę Bożą. Rz 12-1-2 jako fundamentalna zasada etyki św. Pawła, w: Patrzymy na Jezusa, który nam w wierze przewodzi (Hbr 12,2). Księga Pamiątkowa dla ks. prof. Jana Łacha w 85 rocznice urodzin, red. W. Chrostowski, B. Strzałkowska, Warszawa 2012, s. 126-145.

27 Por. J. Strong, LL.D., S.T.D, Grecko-polski słownik Stronga z lokalizacją słów greckich $i$ kodami Popowskiego, dz. cyt., G2307.

28 Por. Mt 6, 10; 7, 21; 12, 50; 18, 14; 21, 31; 26, 42; Mk 3, 35; Łk 12, 47(2x); 22, 42; 23, 25; J 1, 13(2x); 4, 34; 5, 30(2x); 4, 34; 5, 30(2x); 6, 38(2x).39.40; 7, 17; 9, 31; Dz 13, 22; 21, 14; 22, 14; Rz 1, 10; 2, 18; 12, 2; 15, 32; 1 Kor 1, 1; 7, 37; 16, 12; 2 Kor 1, 1; 8, 5; Ga 1, 4; Ef 1, 1.5.9.11; 2, 3; 5, 17; 6, 6; Kol 1, 1.9; 4, 12; 1 Tes 4, 3; 5, 18; 2 Tm 1, 1; 2, 26; Hbr 10, 7.9.10.36; 13, 21; 1 P 2, 15; 3,$17 ; 4,2.19 ; 2$ P 1, 21; 1 J 2, 17; 5, 14; Ap 4, 11. 
Kolejny aspekt to ten, że Paweł odwołuje się do woli Boga, gdy uzasadnia paraklezę, zachęty wynikające z dzieła zbawczego, kierowane do chrześcijan. W Pierwszym Liście do Tesaloniczan stwierdza: „wolą Bożą jest wasze uświęcenie" $(4,3)$. Świętość ludzi jest pierwszym zamierzeniem woli Boga. Użyty tu przez Pawła rzeczownik $\alpha \gamma \iota \alpha \sigma \mu o ́ s$ oznacza zarówno „poświęcenie”, „oczyszczenie”, jak i „uświęcenie serca i życia"29. W Corpus Paulinum występuje on 8 razy (por. Rz 6, 19. 22; 1 Kor 1, 30; 1 Tes 4, 3. 4. 7; 2 Tes 2, 13; 1 Tm 2, 15). W badanym miejscu Paweł pokazuje proces, przez który dokonuje się uświęcenie. Wskazuje na stan początkowy, jak i wciąż trwający ${ }^{30}$. Dokonującym dzieła uświęcenia jest Bóg. Objawia się ono w konkretnych postawach wierzących, którzy odrzucają pożądliwości cielesne, panują nad sobą i przeżywają

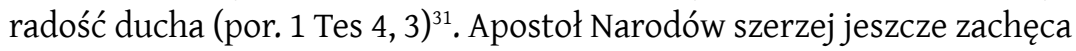
do wypełniania woli Boga, gdy pisze: „zawsze się radujcie, nieustannie się módlcie! W każdym położeniu dziękujcie, taka jest bowiem wola Boża w Jezusie Chrystusie względem was" (1 Tes 5, 18). Paweł poucza Tesaloniczan, że wdzięczność wobec Boga warto okazywać w różnych okolicznościach, a nawet w każdej sytuacji. Zdaje sobie sprawę, że owe okoliczności i sytuacje bywają nieraz dotkliwe, dlatego zaraz dodaje, że wszystko, co ich spotka, podyktowane jest decyzją Boga. Chrześcijan winien przyjąć te wydarzenia w duchu wdzięczności względem Boga ${ }^{32}$. Osią tego dialogu z Bogiem jest Chrystus.

Wydaje się, że rozeznawanie woli Boga w życiu codziennym związane jest z pamięcią o zbawczym dziele Chrystusa, przez które Bóg oczyszcza oraz uświęca serca i ciała wierzących. Ponadto wolą Boga jest,

29 Por. R. Popowski, Wielki słownik grecko-polski Nowego Testamentu, dz. cyt., 40.

30 Por. M. Bednarz, Pierwszy i Drugi List do Tesaloniczan, Częstochowa 2006, s. 284 (NKB NT 13); por. także: P. Kosiłowski, Wiara i czystość. Egzegeza 1 Tes 4, 1-8, w: Żyjemy dla Pana (Rz 14, 8). Studia ofiarowane Siostrze Profesor Ewie J. Jezierskiej OSU, red. W. Chrostowski, Warszawa 2006, s. 218-247.

31 Por. A. Jankowski, Zamiast nieczystości - świętość. Chrześcijański etos małżeństwa według 1 Tes 4, 1-8, w: Jan Paweł II, Mężczyzną i niewiastą stworzył ich, Lublin 1993, s. 175-190 (Jan Paweł II Naucza, 3).

32 Por. M. Bednarz, Pierwszy i Drugi List do Tesaloniczan, Częstochowa 2006, s. 409-410 (NKB NT 13); por. także: K. Romaniuk, „W każdym położeniu dziękujcie”, „W drodze” 17 (1989) nr 8, s. 12-15. 
by chrześcijanie pamiętali nieustannie o radości, modlitwie i dziękczynieniu oraz odkrywali swą misję i godność głosiciela Ewangelii.

Drugim kryterium rozeznawania jest wybór tego, co jest dobre (por. Rz 12, 2). Przymiotnik ơ $\gamma \alpha \theta$ ós oznacza, że coś jest „dobrego charakteru”, „dobrej natury”, „pożyteczne”, „zbawienne”, „dobre”, „, ładne”, „przyjemne”, „radosne”, „szczęśliwe”, „doskonałe”, „wybitne”, „prawe”, „czcigodne" ${ }^{33}$. W Corpus Paulinum przymiotnik ten występuje najczęściej w Liście do Rzymian ${ }^{34}$. W jakich kontekstach i znaczeniu używa Paweł tego przymiotnika? Odnoszony jest on do „dobrych uczynków” (Rz 2, 7), do „przykazań” (Rz 7, 12), do pozytywnej przestrzeni ludzkiego serca (por. Rz 7, 18), do dobra moralnego (por. Rz 7, 19), do dobra, które Bóg rozwija w człowieku (por. Rz 8, 28), do dobrej Ewangelii (por. Rz 10, 15); do wartości, za którą chrześcijanie podążają (por. Rz 12, 9), do wartości, dzięki której wierzący przezwyciężają zło (por. Rz 12, 21), do wartości, o którą wierzący starają się dla zbudowania innych (por. Rz 15, 2); do wartości, która wymaga mądrości (por. Rz 16, 19). Wydaje się słuszne spostrzeżenie św. Pawła, że to, co dobre wymaga badania i rozeznania. Prawdziwa wartość myśli, słów, postaw i wyborów nie zawsze jest łatwa do rozpoznania dla powierzchownego obserwatora. Choć przymiotnik ten odnoszony jest do wartości ziemskich, to jednak je przewyższa i przekracza, kierując uwagę ku dziełu Boga, które uszczęśliwia człowieka i zbawia go. Chrześcijanin rozeznając i wybierając dobro, odnosi się do dobra wiecznego, do dobroci Boga.

Trzecim kryterium pomocnym do badania, rozeznawania i wybierania wskazanym przez Pawła jest pytanie o to, co podoba się Bogu.

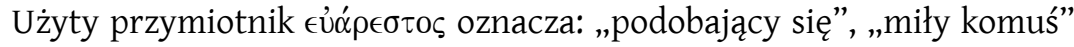
$\left(\right.$ Rz 12, 2) ${ }^{35}$. Zwykle przy jego użyciu wskazuje się na podobające się Bogu działanie (por. Ef 5, 10; Tt 2, 9). W najbliższym kontekście Paweł

33 Por. J. Strong, LL.D., S.T.D, Grecko-polski słownik Stronga z lokalizacją słów greckich i kodami Popowskiego, dz. cyt., G18.

${ }_{34}$ Por. Rz 2, 7.10; 3, 8; 5, 7; 7, 12.13(2x).18.19; 8, 28; 9, 11; 10, 15; 12, 2.9.21; 13, 3(2x).4; 14, 16; 15, 2; 16, 19; 2 Kor 5, 10; 9, 8; Ga 6, 6.10; Ef 2, 10; 4, 28.29; 6, 8; Flp 1, 6; Kol 1, 10; 1 Tes 3, 6; 5, 15; 2 Tes 2, 16.17; 1 Tm 1, 5.19; 2, 10; 5, 10; 2 Tm 2, 21; 3, 17; Tt 1, 16; 2, 5.10; 3,1; Flm 1, 6.14.

35 Por. J. Strong, LL.D., S.T.D, Grecko-polski słownik Stronga z lokalizacją słów greckich $i$ kodami Popowskiego, dz. cyt., G2101. 
charakteryzuje nim ofiarę, jaką chrześcijanie składają Bogu z samych siebie (por. Rz 12,1). W innym miejscu odnosi go do człowieka, który stara się o sprawiedliwość, pokój, radość w Duchu Świętym i w ten sposób staje się „podobającym się Bogu” (Rz 14, 18). Kiedy wierzący żyją nadzieją wieczności w swych codziennych wyborach, wówczas stają się - „podobającymi się" Bogu (por. 2 Kor 5, 9). W Liście do Filipian (por. 4, 18) Paweł precyzuje, że okazaną mu pomoc widzi jako miłą ofiarę przyjętą przez Boga i chce, aby również inni tak ją rozumieli jako bardzo miłą ofiarę przyjętą przez Boga ${ }^{36}$. Kiedy Paweł zachęca dzieci, by były posłuszne rodzicom „we wszystkim”, jako uzasadnienie, podaje motywację chrystologiczną: „bo to jest podobające się Panu” (Kol 3, 20). Prawdopodobnie autor chciał w ten sposób wskazać adresatom wzór całkowitego posłuszeństwa, jaki Chrystus dał chrześcijanom, gdy stał się „posłuszny aż do śmierci" (Flp 2, 8) ${ }^{37}$. Rozeznawanie i wybieranie w codzienności tego, co jest „podobające się” Bogu wydaje się podprowadzać wierzących do postawy hojności serca zarówno wobec Boga,jak i człowieka. Kluczem w rozeznawaniu jest postawa ofiarowania się, uległości i zawierzenia we wszystkim Bogu jako Panu.

Czwarte kryterium w rozeznawaniu, które podaje Paweł Apostoł, to szukanie tego, co doskonałe. Przymiotnik $\tau$ té $\lambda \in \operatorname{los}$ oznacza rzeczywistość „doprowadzoną do końca”, „dokończoną”, „niemającą jakichkolwiek braków”, „doskonałą”. W odniesieniu do ludzi przymiotnik ten oznacza: „dorosły”, „dojrzały”, „prawy”, „cnotliwy”38. W Nowym Testamencie pojęcie to odnosi się do życia chrześcijańskiego. Sporo światła na zrozumienie jego treści i wagi wnosi św. Mateusz, który stosuje

36 Por. J. Flis, List do Filipian, dz. cyt., s. 454; por. także: E. J. Jezierska, „Dobry czyn człowieka - wdzięczna wonnością” Bogu. Refleksje w oparciu o Ef 5, 2 i Flp 4, 18, „Poznańskie Studia Teologiczne" 6 (1986), s. 21-25.

37 Por. B. Adamczewski, List do Filemona. List do Kolosan, Częstochowa 2006, s. 331 (NKB NT 12); por. A. Sikora, Rodzina w nowotestamentalnych ,tablicach domowych”, w: Biblia o rodzinie, red. G. Witaszek, Lublin 1995, s. 47-67.

38 Por. J. Strong, LL.D., S.T.D, Grecko-polski słownik Stronga z lokalizacją słów greckich i kodami Popowskiego, dz. cyt., G5046. Termin telos znany w XXL jako oddający hebr. tāmîm określa drogę Bożą jako nieskalaną (por. 2 Sm 22, 31). Tak więc Noe wyróżniał się nieskalanością $(\mathrm{Rdz} 6,9)$. Baranek wybierany na wieczerzę winien być bez skazy (por. Wj 12, 5), a nawet drzewo do obróbki powinno być nieskazitelne (por. Ez 15, 5). 
go dwukrotnie. Najpierw przekazuje na końcu Kazania na Górze zachętę Chrystusa do doskonałości, przez którą chrześcijanie odzwierciedlają podobieństwo do Ojca: „Bądźcie więc wy doskonali, jak doskonały jest Ojciec wasz niebieski" (Mt 5, 48) ${ }^{39}$. Następnie przypomina zachętę Jezusa skierowaną do bogatego młodzieńca: „Jeśli chcesz być doskonały, idź, sprzedaj, co posiadasz, i rozdaj ubogim, a będziesz miał skarb w niebie. Potem przyjdź i chodź za Mną!" (Mt 19, 21).

Wydaje się, że zaproszenie do dojrzałości, skierowane jest do wszystkich wierzących, oznacza najpierw - zaangażowanie w proces, a następnie - proces ten wymaga wyrzeczenia się przywiązania do dóbr ziemskich, powierzenia się Bogu i zaangażowania w naśladowanie Chrystusa. Zastosowanie tego przymiotnika w Corpus Paulinum zwykle związane jest z ukazywaniem człowieka dojrzałego, jakim wierzący stają się przez zjednoczenie z Chrystusem. W Pierwszym Liście do Koryntian Paweł przymiotnikiem $\tau$ té $\lambda \in \operatorname{l}$ o określa ludzi żyjących już łaską chrztu i duchem Ewangelii (por. 1 Kor 2, 6). Następnie zachęca ich do rozeznawania i dojrzałego myślenia (por. 1 Kor 14, 20). Chrześcijanie mają stać się „,doskonali" w wypełnianiu woli Bożej (por. Kol 4, 12; Ef 4, 13) ${ }^{40}$. W Liście do Efezjan autor ukazuje obraz dochodzenia wszystkich wierzących do „Męża doskonałego" (por. 4, 13). Obraz ten zawiera myśl o dynamicznych i ukierunkowanych ku Chrystusowi jakościowych zmianach, które dokonują się w chrześcijanach tworzących Ciało Chrystusa. Są to przemiany wydoskonalające Ciało Chrystusa i zbliżające wierzących do Pana. U początku, w trakcie i w końcu tego procesu jest Chrystus ${ }^{41}$.

W tym miejscu należy jeszcze dodać, że dar rozeznania, o jaki Paweł modli się dla Filipian, jest łaską, dzięki której człowiek nabywa roztropności i zdolności oceny sytuacji, posiada też duchowy zapał, aby

39 Por. Ordon H., Powiedziano przodkom... a ja wam powiadam (Mt 5, 21-48). Antytezy kazania na górze, „Roczniki Teologiczno-Kanoniczne” 51 (2004) nr 1, s. 79-92.

40 Por. J. Flis, List do Filipian, dz. cyt., s. 378.

${ }_{41}$ Por. A.E. Klich, Kościót Chrystusa wspólnotą w Duchu Świętym, Kraków 2008, s. 85; por. także: S. Chłąd, Aner Teleios według Ef 4, 13, w: Agnus et Sponsa, red. T. M. Dąbek, T. Jelonek, Kraków 1993, s. 19-28; S. Chłąd, Kościót chwalebnego Chrystusa. Doktryna 4, 7-16 na tle paralel nowotestamentowych, Warszawa 2000 (Rozprawy i Studia Biblijne, 6); S. Chłąd, Chrystus i Kościót według Ef 4, 7-16, „Częstochowskie Studia Teologiczne” 19-20 (1991/1992), s. 7-21. 
rozpoznawać i wypełniać wolę Boga ${ }^{42}$. Dar ten ma kluczowe znaczenie dla życia chrześcijańskiego. Zaangażowana współpraca z tym darem przejawia się w codziennej trosce o to, by Chrystus, z którym wierzący są zjednoczeni przez chrzest, stawał się coraz bardziej widoczny w stylu życia. Ponadto odnajdywanie woli Boga wymaga wsłuchiwania się w głos sumienia, w słowo Boże oraz przyjęcia tego, do czego wierzący jest zapraszany: chodzi o miłość aż po oddanie życia.

\section{Perspektywa wieczności}

W swej modlitwie apostolskiej (por. Flp 1, 9-11) św. Paweł zauważa, że wybór i życie w wierności Chrystusowi oraz podążanie za Nim ściśle wiąże się z „czystością i byciem bez zarzutu na Dzień Pana” $(1,10)$. Wskazuje tu najpierw na troskę o czystość serca. Zastosowany w bada-

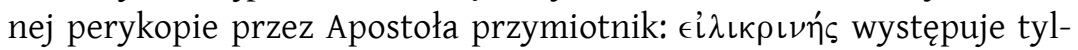
ko raz w Corpus Paulinum i oznacza „czysty”, „szczery”, „nieskażony”, „Czysty po odsłonięciu w świetle słońca”43. Związany z nim rzeczownik

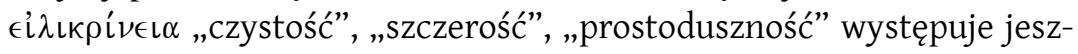
cze u Pawła, gdzie łączy on postawę czystości z prawdą (por. 1 Kor 5, 8) oraz z prostotą serca i szczerością wobec Boga (por. 2 Kor 1, 12). Dru-

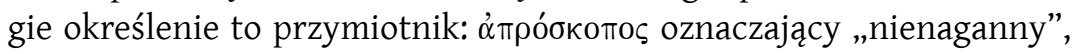
„bez zarzutu”, „nieprowadzący innych do grzechu przez swój sposób życia"44. Przymiotnik ten występuje poza badanym miejscem jeszcze tylko w 1 Kor 10, 32, gdzie Paweł domaga się „nienagannego” życia wobec wszystkich. Ponadto w Dziejach Apostolskich Apostoł zapewnia, że zawsze usilnie się stara, aby mieć zawsze „czyste” sumienie wobec Boga i wobec ludzi $(24,16)$.

${ }^{42}$ Dar rozeznawania woli Bożej nie jest tożsamy z charyzmatem rozeznawania duchów (por. 1 Kor 12,10), który jest związany z prorokowaniem i prowadzi do rozpoznania, jaki duch inspiruje mówiącego: Duch Święty, duch Antychrysta $(1 \mathrm{~J} 4,4)$ czy też ludzka wyobraźnia; por. J. Kudasiewicz, Duch Święty i Jego dary, Kraków 2007, s. 85.

${ }_{43}$ Por. J. Strong, LL.D., S.T.D, Grecko-polski słownik Stronga z lokalizacją słów greckich i kodami Popowskiego, dz. cyt., G1506.

${ }_{44}$ J. Strong, LL.D., S.T.D, Grecko-polski słownik Stronga z lokalizacją słów greckich $i$ kodami Popowskiego, dz. cyt., G677. 
Analogiczne zestawienie podobnych przymiotników obecne jest w innych miejscach Corpus Paulinum (por. Ef 1, 4; Ef 5, 27; Kol 1, 22). Autor Listu do Efezjan dwukrotnie określa Kościół przymiotnikami „święty i nieskalany" (Ef 1, 4; 5, 27). W perykopie Ef 5, 21-33 ofiarna i zbawcza miłość Chrystusa do Kościoła - Jego Oblubienicy ukazana jest w dwóch aktach ${ }^{45}$. Pierwszy - dobrowolnie podjęta śmierć przez Chrystusa, który „samego siebie wydał za nią" (w. 25). Drugi - zastosowanie skutków śmierci Chrystusa do obmycia chrzcielnego, a więc do oczyszczenia, które zmierza do ostatecznego upiększenia Oblubienicy, to jest do uświęcenia Kościoła już w fazie eschatologicznej (w. 27). W dalszym wywodzie Kościół Oblubienicę Chrystusa opisuje za pomocą czterech wyrażeń. Pierwsze

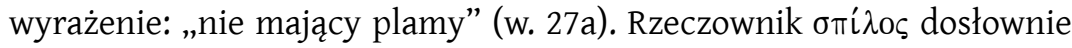
oznacza „plamę” lub „skazę”, przenośnie oznacza skazę moralną. Drugie wyrażenie: „[nie mający] zmarszczki” (w. 27b). Rzeczownik ṕu í stanowi hapax legomenon biblijny. Znany był dobrze klasykom greckim i oznaczał objaw starości. Według Hieronima chodzi o ślady „starego człowieka”. Kolejne terminy występują razem: „święty i nieskalany” (w. 27c; por. Ef 1, 4; Kol 1, 22). W Liście do Efezjan autor stwierdza: „W Nim [w Chrystusie] wybrał nas przed założeniem świata, abyśmy byli święci i nieskalani przed Jego obliczem" $(1,4)$. A postoł uwydatnia tu zamierzony przez Boga skutek przynależności wiernych do Chrystusa ${ }^{46}$. W Liście do Kolosan św. Paweł pisze: „teraz znów pojednał [Bóg] w doczesnym Jego ciele przez śmierć, by stawić was przed sobą jako świętych i nieskalanych,

45 Celem zbawczej miłości Chrystusa jest pełne uświęcenie Kościoła jako dostojnej Oblubienicy $(E f 5,27)$ wzorem sytuacji z Ps 44(45), 10, gdzie mowa jest o przyprowadzeniu przed Oblubieńca przyodzianej w strój ślubny oblubienicy. W badanej perykopie Chrystus jest Tym, który stawia ją przed sobą samym. Nie korzysta z niczyjej usługi - ojca, drużbów, ewangelicznych „gości weselnych” (Mt 9, 15), ani „przyjaciół oblubieńca (J 3, 29). Paralela do Godów baranka z Apokalipsy $(19,7-9 ; 21,9)$ skłania do uznana sensu eschatologicznego. Por. J. Kudasiewicz, Geneza Pawłowej symboliki małżenstwa, „Roczniki Teologiczno-Kanoniczne” (1958) z. 2, s. 21-26; A. Suski, Pieśń o miłości Chrystusa do Kościoła (Ef5, 25b-27), „Studia Theologica Varsaviensia" (1979) nr 2, s. 3; J. Kułaczkowski, Aspekty miłości męża do żony w świetle Listu do Efezjan 5, 25-30, „Ateneum Kapłańskie” (2007) nr 2, s. 306; A.E. Klich, Miłosierdzie Boga odpowiedzią na ludzką zdradę. Ez 16 odczytany przez Ef 5, 25b-27, w: Bądźcie świadkami miłosierdzia, red. R. Ceglarek, A. Kulierda, Częstochowa 2017, s. 19-32.

46 Por. A. Jankowski, Listy więzienne świętego Pawła. Do Filipian - do Kolosan - do Filomena do Efezjan. Wstęp - przekład z oryginału - komentarz, Poznań 1962, s. 366. 
i bez zarzutu" $(1,22)^{47}$. Autor mówiąc o skutkach Odkupienia, widzi je już w fazie ostatecznej realizacji. Dwa pierwsze terminy określające skutki pojednania: „święty i nieskalany” należą do słownictwa sakralnego (por. Lb 16, 7; Kpł 1, 10; Hbr 9, 14; 1 P 1, 19), ale odnoszone są też na oznaczenie doskonałości moralnej (por. Flp 2, 15, Ap 14, 5) ${ }^{48}$. Nagromadzenie tylu określeń dotyczących piękności Kościoła jest nawiązaniem do tekstów Starego Testamentu, które sławią Izraela czy Jerozolimę jako Oblubienicę Jahwe (por. Pnp 4, 1-5; 6, 1.4-7; 7, 2-10; Iz 61, 10; Ba 5, 2; Ez 16, 9-14). Odniesienie ich do Kościoła akcentuje owoce zbawczej miłości Chrystusa do Kościoła - Oblubienicy.

Podsumowując powyższe analizy należy stwierdzić, że „czystość i nienaganność”, o którą modli się Paweł dla Filipian ma podwójne znaczenie. Po pierwsze - postawy te są znakiem otwartości na dar zbawienia i moc obmycia chrzcielnego; po drugie - wskazują na oblubieńczą więź z Chrystusem.

W badanej perykopie modlitwa wstawiennicza Pawła za chrześcijan dotyczy tego, by byli „czyści i bez zarzutu” na „dzień Chrystusa”

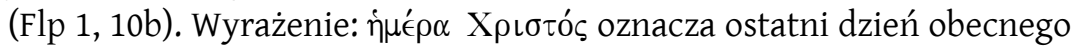
wieku, dzień, kiedy Chrystus przyjdzie powtórnie, wskrzesi umarłych, dokona sądu i zaprowadzi pełnię swego Królestwa ${ }^{49}$. Konstrukcja zdania z przyimkiem €iৎ pozwala przyjąć, że chodzi zarówno o kres czasu, jak i o cel. Można więc uznać, że Paweł stara się wskazać, iż wszystko, co czynią chrześcijanie, ma swoje znaczenie i powinno być czynione ze względu na dzień Chrystusa. Zachęta, by być „czystym” i „bez zarzutu" odnosi się więc nie tylko do dnia ostatecznego, ale również do współczesności. Dlatego tak ważna jest modlitwa i troska o rozeznawanie w codzienności.

47 Por. B. Adamczewski, List do Filemona. List do Kolosan, Częstochowa 2006, s. 219n (NKB NT 12).

48 Por. A. Jankowski, Listy więzienne świętego Pawła..., dz. cyt., s. 242. 486, por. także: S. Mędala, Tajemnica Bożej ekonomii zbawienia (List do Efezjan), w: Wprowadzenie w myśl $i$ wezwanie ksiag biblijnych, t. 9: Dzieje Apostolskie. Listy św. Pawła, oprac. A.S. Jasiński, S. Mędala, G. Rafiński, W. Rakocy, H. Skoczylas, B. Widła, Warszawa 1997, s. 479.

49 Por. J. Strong, LL.D., S.T.D, Grecko-polski słownik Stronga z lokalizacją słów greckich $i$ kodami Popowskiego, dz. cyt., G2250. 
Apostoł Narodów swą modlitwę zamyka frazą: „napełnieni plonem sprawiedliwości, [nabytym] przez Jezusa Chrystusa ku chwale i czci Boga” (Flp 1,11). W wersecie tym kontynuowana jest myśl o przygoto-

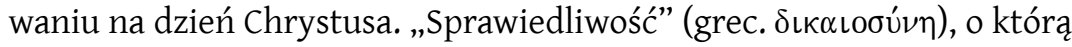
modli się Paweł przychodzi „przez” Chrystusa i „dzięki” Niemu. W Liście do Filipian wskazuje na sprawiedliwość wynikającą z „wiary w Jezusa”, a nie na „moją sprawiedliwość” pochodzącą z Prawa. Owa sprawiedliwość płynąca z wiary jest oczywiście sprawiedliwością darowaną przez Boga. Paweł potwierdza to przekonanie przez porównanie ze swoim dawnym doświadczeniem, gdy na podstawie sprawiedliwości wynikającej z Prawa, uważał się za osobę „bez zarzutu” (Flp 3, 6). Taki moralny perfekcjonizm, jaki Paweł posiadał ze względu na swoje pochodzenie i osobiste starania, nie prowadzi jednak do właściwej relacji z Bogiem ${ }^{50}$. Przeciwnie, to Chrystus usprawiedliwia wierzących i prowadzi do komunii ze sobą. Sprawiedliwość oznacza więc kroczenie Jego drogą, wyzbycie się siebie, aby nie służyć egoistycznej ambicji, ale naśladować chrystusa w uniżaniu siebie samego, aby dojść do punktu, w którym jest się zdolnym nawet umrzeć za innych. Nie ma już w niej miejsca dla „próżnej zarozumiałości” (por. 2, 3-8). To właśnie znaczy dla Pawła „poznać Chrystusa” ${ }^{51}$.

Modlitwa wstawiennicza kończy się zwrotem: „na chwałę i cześć Boga” (w. 11b). Ostatecznym celem życia chrześcijańskiego jest Bóg. Doksologiczne formuły są typowe dla zakończeń modlitw żydowskich ${ }^{52}$. Doksologia ta wyróżnia się tym, że wysławianie Boga powiązane jest z Chrystusem ${ }^{53}$. Paweł stosuje tu dwa terminy, które są niemal synonimami. Pierwszy z nich, rzeczownik dó $\alpha$ dosłownie oznacza „chwałę” i „majestat” Boga, Chrystusa i ludzi przez udział w życiu Boga ${ }^{54}$. Poprzez

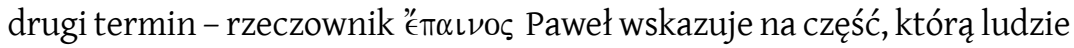
oddają i winni oddawać Bogu, gdyż to jest sprawiedliwe, godne, czyste,

50 Por. K.L. Onesti, M.T. Brauch, Sprawiedliwość, w: Słownik Teologii św. Pawła, red. G.F. Hawthorne, R. P. Martin, D.G. Reid, Warszawa 2010, s. 770.

51 Por. J. Flis, List do Filipian, dz. cyt., s. 116.

52 Por. 2 Sm 22, 50; Ps 21 14; 35 28; 41, 14; 45, 18; 66, 20; 72, 18; 89, 53; 106, 48; 145, 21, 150; Syr 39, 10.

53 Por. J. Gnilka, Der Philipperbrief, dz. cyt., s. 53.

54 Por. R. Popowski, Wielki słownik grecko-polski Nowego Testamentu, dz. cyt., 1389. 


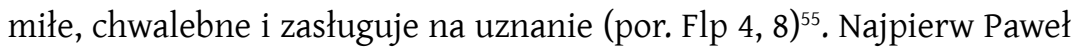
„dziękował swojemu Bogu” (1, 3), a na końcu modlitwy zaznacza, że celem rozeznawania jest „chwała Boga” $(1,11)$.

Podsumowując należy stwierdzić, że modlitwa wstawiennicza Pawła zanoszona do Boga za Filipian (1, 9-11) wskazuje na to, że rozeznawanie jest darem, łaską, o którą warto prosić dla siebie, dla innych, dla całego Kościoła. Dzięki współpracy z tą łaską chrześcijanie coraz bardziej upodabniają się do Chrystusa. Apostoł Narodów podkreśla, że rozeznawanie łączy się ściśle ze wzrostem w miłości, ale też z otwieraniem się na poznanie objawiającego się Boga. Kluczową kwestią w rozeznawaniu - dla Pawła - jest odnajdywanie tego, co jest wartościowe. Odczytując tę zasadę poprzez Rz 12, 2 można przyjąć, że chodzi o to, co dobre - pomocne do zbawienia, o to, w czym Bóg ma upodobanie - czystość serca i całkowite ofiarowanie się Jemu i to, co doskonałe, dojrzałe.

\section{Bibliografia}

Adamczewski B., List do Filemona. List do Kolosan, Częstochowa 2006 (NKB NT 12).

Bednarz M., Pierwszy i Drugi List do Tesaloniczan, Częstochowa 2006 (NKB NT 13).

Chłąd S., Aner Teleios według Ef 4, 13, w: Agnus et Sponsa, red. T. M. Dąbek, T. Jelonek, Kraków 1993, s. 19-28.

Chłąd S., Chrystus i Kościół według Ef 4, 7-16, „Częstochowskie Studia Teologiczne” 19-20 (1991/1992), s. 7-21.

Chłąd S., Kościót chwalebnego Chrystusa. Doktryna 4, 7-16 na tle paralel nowotestamentowych, Warszawa 2000 (Rozprawy i Studia Biblijne, 6).

Dąbek T. M., Hymn o miłości (1 Kor 12, 31-13, 13), w: Aby rozważać Pismo Święte, T. M. Dąbek, E. Wiater, W. Zatorski, L. Mycielski, Kraków 2011, s. 187-199.

Flis J., List do Filipian, Częstochowa 2011 (NKB NT 11).

Franciszek, Posynodalna adhortacja apostolska Amoris laetitia (19 marca 2016), Kraków 2016.

Gieniusz A., Boże miłosierdzie jako źródło chrześcijańskiego nonkonformizmu Rz 12, 1-2, „Verbum Vitae” 2 (2003) nr 3, s. 139-161.

Gnilka J., Der Philipperbrief, Freiburg-Basel-Wien 1968 (Herders Theologischer Kommentar zum Neuen Testament, 10).

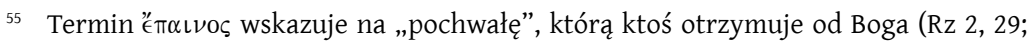
1 Kor 4,5$)$, ale także od władzy (Rz 13, 3). Może oznaczać również sławę rozszerzającej się Ewangelii $(2$ Kor 8,18$)$ oraz chwałę Boga i Jego majestatu (Ef 1, 6.12.14). Termin ten może również wskazywać na przedmiot pochwały (Flp 4, 8). Por. J. Flis, List do Filipian, dz. cyt., s. 117. 
Gryziec P., Rozpoznać wolę Bożą. Rz 12-1-2 jako fundamentalna zasada etyki św. Pawła, w: Patrzymy na Jezusa, który nam w wierze przewodzi (Hbr 12,2). Księga Pamiątkowa dla ks. prof. Jana Łacha $w 85$ rocznicę urodzin, red. W. Chrostowski, B. Strzałkowska, Warszawa 2012 , s. 126-145.

Jankowski A., Listy więzienne świętego Pawła. Do Filipian - do Kolosan - do Filomena do Efezjan. Wstęp - przekład z oryginału - komentarz, Poznań 1962.

Jankowski A., Zamiast nieczystości - świętość. Chrześcijański etos małżeństwa według 1 Tes 4, 1-8, w: Jan Paweł II, Mężczyzną i niewiasta stworzył ich, Lublin 1993, s. 175-190 (Jan Paweł II Naucza, 3).

Jezierska E.J., „Dobry czyn człowieka - wdzięczna wonnościa” Bogu. Refleksje w oparciu o Ef 5, 2 i Flp 4, 18, „Poznańskie Studia Teologiczne” 6 (1986) s. 21-25.

Kasprzyk A., Znaczenie kenozy Chrystusa dlajedności wspólnoty, w: Powołani do komunii z Bogiem i człowiekiem, red. A. E. Klich, Kraków 2011, s. 51-76 (Duc in Altum, 12).

Klich A.E., Kościót Chrystusa wspólnota w Duchu Świętym, Kraków 2008.

Klich A.E., Miłosierdzie Boga odpowiedzia na ludzką zdradę. Ez 16 odczytany przez Ef 5 , 25b-27, w: Bądźcie świadkami miłosierdzia, red. R. Ceglarek, A. Kulierda, Częstochowa 2017, s. 19-32.

Kudasiewicz J., Duch Święty i Jego dary, Kraków 2007.

Kułaczkowski J., Aspekty miłości męża do żony w świetle Listu do Efezjan 5, 25-30, „Ateneum Kapłańskie" (2007) nr 2, s. 305-314.

Kosiłowski P., Wiara i czystość. Egzegeza 1 Tes 4, 1-8, w: Żyjemy dla Pana (Rz 14, 8). Studia ofiarowane Siostrze Profesor Ewie J. Jezierskiej OSU, red. W. Chrostowski, Warszawa 2006, s. 218-247.

Kramarz D., Analiza struktury literackiej Rz 12, 1-21, w: Hermeneutyka Pisma Świętego w Kościele. Wokót adhortacji „Verbum Domini” Benedykta XVI o słowie Bożym w życiu i misji Kościoła, red. R. Pindel, S. Jędrzejewski, Kraków 2012, s. 123-152 (Hermeneutica et Judaica, 6).

Kudasiewicz J., Geneza Pawłowej symboliki małżeństwa, „Roczniki Teologiczno-Kanoniczne" (1958) z. 2, s. 5-30.

Langkammer H., Pismo Święte Starego i Nowego Testamentu w przekładzie z języków oryginalnych. List do Rzymian. Tłumaczenie. Wstęp. Komentarz, Lublin 1999.

Langkammer H., Pismo Święte Starego i Nowego Testamentu. Pierwszy i Drugi List do Koryntian. Thumaczenie. Wstęp i Komentarz, Lublin 1998.

Levison J.R., Stworzenie i nowe stworzenie; w: Stownik teologii św. Pawła, red. G. F. Hawthorne, R.P. Martin, D. G. Reid, Warszawa 2000, s. 792-793.

Mędala S., Tajemnica Bożej ekonomii zbawienia (List do Efezjan), w: Wprowadzenie w myśl i wezwanie ksiag biblijnych, t. 9: Dzieje Apostolskie. Listy św. Pawła, oprac. A.S. Jasiński, S. Mędrala, G. Rafiński, W. Rakocy, H. Skoczylas, B. Widła, Warszawa 1997.

Onesti K.L., Brauch M. T., Sprawiedliwość, w: Stownik Teologii św. Pawła, red. G.F. Hawthorne, R.P. Martin, D. G. Reid, Warszawa 2010, s. 770.

Ordon H., Powiedziano przodkom... a ja wam powiadam (Mt 5, 21-48). Antytezy kazania na górze, „Poznańskie Studia Teologiczne” 51 (2004) nr 1, s. 79-92.

Paciorek A., Drugi List do Koryntian, Częstochowa 2017 (NKB NT 8). 
Popowski R., Wielki słownik grecko-polski Nowego Testamentu, Warszawa 2006.

Romaniuk K., ,W każdym położeniu dziękujcie”, „W drodze” 17 (1989) nr 8, s. 12-15.

Ruszała A., W dobrych zawodach. Rozeznanie i walka duchowa w życiu chrześcijańskim, Kraków 1999.

Sikora A., Rodzina w nowotestamentalnych ,tablicach domowych”, w: Biblia o rodzinie, red. G. Witaszek, Lublin 1995, s. 47-67.

Strong J., LL.D., S.T.D, Grecko-polski słownik Stronga z lokalizacją słów greckich i kodami Popowskiego, Warszawa 2015.

Suski A., Pieśń o miłości Chrystusa do Kościoła (Ef 5, 25b-27), „Studia Theologica Varsaviensia" (1979) nr 2, s. 3-42.

Teodoret z Cyru, Komentarz do 1 i 2 Listu do Koryntian, Kraków 1998 (Źródła Myśli Teologicznej, 8).

Witkowski S., Upokorzony i uwielbiony Chrystus (Flp 2, 6-11), „Ruch Biblijny i Liturgiczny" 61 (2008) nr 1, s. 29-38.

Wróbel M. S., Dziękuję Bogu mojemu, z powodu każdego waszego wspomnienia - zawsze w każdej mojej modlitwie... (Flp 1, 3n), w: Modlitwa dziękczynienia, red. J. Misiurek, J.M. Popławski, K. Burski, Lublin 2005, s. 19-29 (Homo Orans, 6). 